\title{
PROBLEMS OF MODERN ACCOUNTING OF FIXED ASSETS
}

\section{Svitlana Sliusar ${ }^{1}$}

DOI: https://doi.org/10.30525/978-9934-588-11-2_70

For today one of the main problems of economy of Ukraine is overcoming output gap on domestic enterprises and maintenance of normal reproduction process on all its links. The main objective of the enterprises is increase in efficiency of use of material and technical resources of the enterprise in the conditions of an acute shortage of investment resources. The most important component of material and technical resources fixed assets.

On which accurate and rational accounting further process of reproduction, updating, replenishment and finally - security of the enterprise with competitive, modern labor instruments depends. Development of this direction of economy depends first of all on timely obtaining reliable, solid and full registration and economic information. In this regard, the role and value of accounting of fixed assets as important function of business management increases.

Fixed assets occupy the main specific weight in the total amount of fixed capital of the enterprise. From quality, costs, technological level of fixed assets, efficiency of their use depend resulting effects of activity of the enterprise: production, its prime cost, profit, profitability, stability of a financial position.

Increase in efficiency of use of fixed assets is one of the main questions during transition to the market relations [3]. The solution of this problem influences a financial condition of the enterprise, competitiveness of its products in the market.

In accounting the task to improve management and control of safety of fixed assets and strengthening of a financial condition of the enterprise, increase in efficiency of activity and reduction of risk of loss of means for unreasoned actions is assigned.

Some of elements of a control system of fixed assets of the enterprise is the economic analysis and audit [2, p. 71]. The analysis of existence and use of fixed assets is the main direction of the analysis in the long term as methodical receptions of the economic analysis allow to define in the presence of the small volume of information on results of activity of economic entity its potential opportunities, internal reserves which use will allow to reach positive changes in financial results of activity (Figure 1).

Control of effective use of fixed assets can be considered as a measure for reduction of the need for the volume of their financing and increase in rates of economic development of the enterprise due to rational use of own financial resources [1, p. 143]. Approach of carrying out internal control is considered allows to construct the rational system of control and auditing procedures of fixed assets that gives the chance, first, to create effective depreciation policy; secondly, in due time to reveal reserves of efficiency of use of fixed assets.

\footnotetext{
${ }^{1}$ Pereiaslav-Khmelnytskyi Hryhorii Skovoroda State Pedagogical University, Ukraine 
Internal control of use of fixed assets of the enterprise

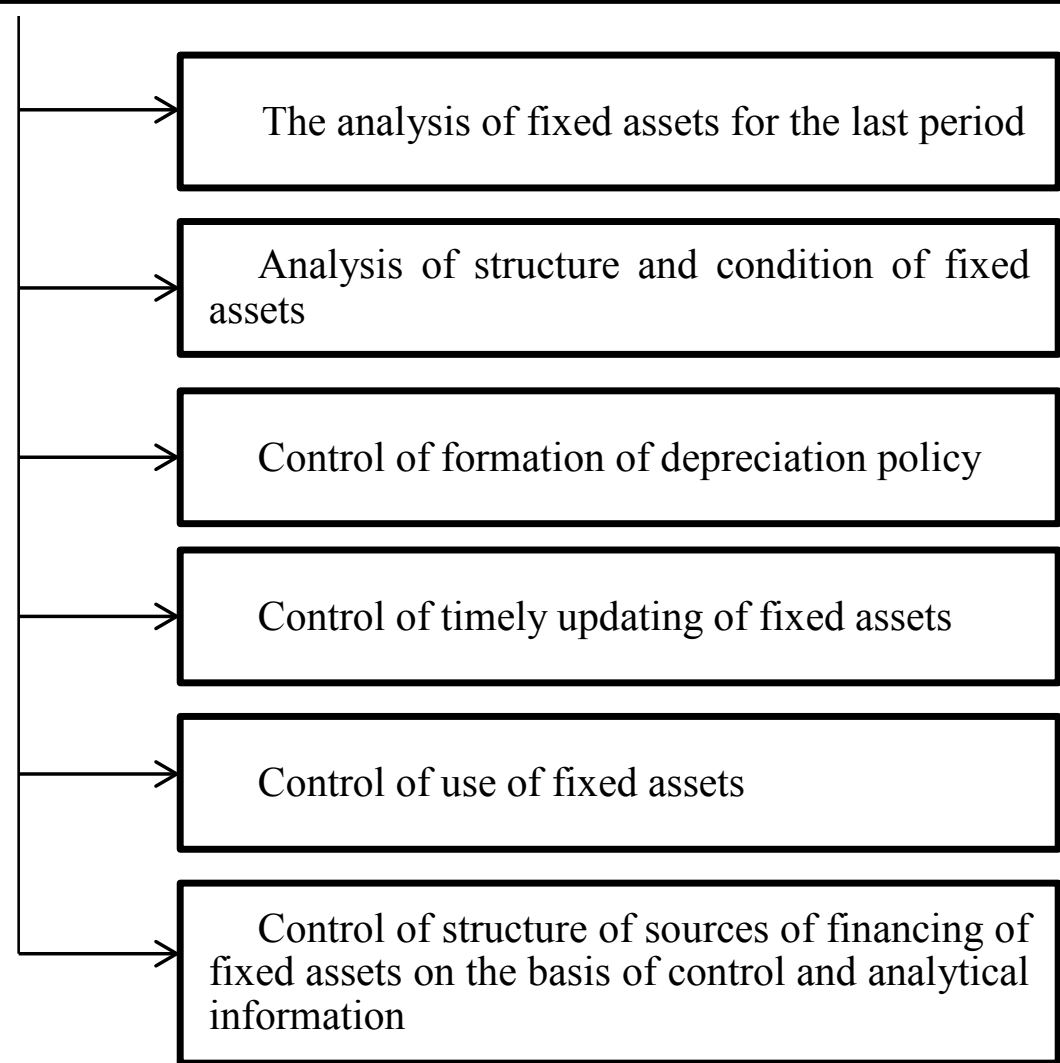

\section{Figure 1. The sequence of internal control in management of fixed assets of the enterprise}

Source: author's development

Thus, in modern conditions of managing, a lack of financial resources, bankruptcies and elimination of subjects of managing and also considering the high level of moral and physical wear of the equipment of the enterprises, more than ever there is a problem of the most rational and effective use of fixed assets.

\section{References:}

1. Borisyuk, A. (2010). Vplyv oblikovoyi polityky na efektyvnist' vykorystannya neoborotnykh aktyviv [Influence of accounting policies on efficiency of use of fixed assets]. Economic sciences. Series: Account and finance, vol. 7(1), pp. 138-149. (in Ukrainian)

2. Peresechanska, A. (2014). Teoretychni aspekty audytu osnovnykh zasobiv [Theoretical aspects of audit of fixed assets]. Management of development, vol. 12. p. 69-71. (in Ukrainian)

3. Platonova, I. Problemy obliku osnovnykh zasobiv v Ukrayini [Problems of accounting of fixed assets in Ukraine] : website. URL: http://intkonf.org/platonova-ia-problemi-oblikuosnovnihzasobiv-v-ukrayini/ (in Ukrainian) 